\title{
Suitability of DNA extracted from archival specimens of fruit-eating bats of the genus Artibeus (Chiroptera, Phyllostomidae) for polymerase chain reaction and sequencing analysis
}

\author{
Mário Pinzan Scatena and Eliana Morielle-Versute \\ Departamento de Zoologia e Botânica, Instituto de Biociências, Letras e Ciências Exatas \\ de São José do Rio Preto, Universidade Estadual Paulista, São José do Rio Preto, SP, Brazil.
}

\begin{abstract}
To establish a technique which minimized the effects of fixation on the extraction of DNA from formalin-fixed tissues preserved in scientific collections we extracted DNA samples from fixed tissues using different methods and evaluated the effect of the different procedures on PCR and sequencing analysis. We investigated muscle and liver tissues from museum specimens of five species of fruit-eating (frugivorous) bats of the Neotropical genus Artibeus (Chiroptera, Phyllostomidae): A. fimbriatus, A. lituratus, A. jamaicensis, A. obscurus, and A. planirostris. The results indicated that treatment of tissues in buffered solutions at neutral $\mathrm{pH}$ and about $37^{\circ} \mathrm{C}$ for at least four days improves the quality and quantity of extracted DNA and the quality of the amplification and sequencing products. However, the comparison between the performance of DNA obtained from fixed and fresh tissues showed that, in spite of the fact that both types of tissue generate reliable sequences for use in phylogenetic analyses, DNA samples from fixed tissues presented a larger rate of errors in the different stages of the study. These results suggest that DNA extracted from formalin-fixed tissue can be used in molecular studies of Neotropical Artibeus bats and that our methodology may be applicable to other animal groups.
\end{abstract}

Key words: archival specimens, Chiroptera, DNA extraction, formalin-fixed.

Received: April 19, 2007; Accepted: July 17, 2007.

Biological collections represent a wealth of biological information that has been carefully documented in a time and space format. Collections often contain hundreds or thousands of animal and plant specimens, many of which have been preserved in such a way as to make scientific investigation possible. In recent years museums have enhanced the relevance of biological collections by modernizing archives of preserved tissues, registering collections and biological studies online and making data sets available for use in related studies (Oliver et al., 2000; Hanner et al., 2005). These materials are sources for tissues, DNA and other complex molecules that provide vast quantities of information on subjects including the history of life and biocomplexity (Corthals and Desalle, 2005).

Despite the fact that liver, kidney, heart, lung, spleen, reproductive organ and other tissues can benefit from modern methods of chemical preservation and cryopreservation that greatly enhance the value of voucher specimens, most

Send correspondence to Eliana Morielle Versute. Laboratório de Chiroptera, Departamento de Zoologia e Botânica, Instituto de Biociências, Letras e Ciências Exatas, Universidade Estadual Paulista, Rua Cristóvão Colombo 2265, 15054-000 São José do Rio Preto, SP, Brazil. E-mail: morielle@ ibilce.unesp.br. tissues are still preserved in fixative mixtures containing formalin, alcohol or both and may suffer damage from formalin-induced cross-links in DNA and protein, which presents special problems when obtaining DNA for amplification using the polymerase chain reaction (PCR).

Extraction of DNA from formalin-fixed, paraffinembedded archival tissue was accomplished as early as 1985 using proteinase K and sodium dodecyl sulfate (SDS) as the major reagents (Goelz et al., 1985; Dubeau et al., 1986). Recent publications have demonstrated that high temperature heating may improve DNA extraction from formalin-fixed and paraffin-embedded archival tissues (Shi et al., 2001). It has been supposed that the same factors (heat and $\mathrm{pH}$ ) that affect antigen retrieval (AR) and immunohistochemical (IHC) staining influence the efficiency of DNA extraction from paraffin-embedded archival tissue (Shi et al., 1991; Frank et al., 1996; Faulkner and Leigh 1998; Coombs et al., 1999; Yamashita et al., 2001), with higher-temperature heating under alkaline conditions providing the most satisfactory results regarding higher DNA yields (Shi et al., 2002).

To establish a technique which minimized the effects of fixation on the extraction of DNA from formalin-fixed 
tissues preserved in scientific collections we extracted DNA samples from fixed tissues of fruit-eating (frugivorous) bats of the Neotropical genus Artibeus (Chiroptera, Phyllostomidae) using different methods, based on the AR technique for proteins involving heating preserved tissues at different $\mathrm{pH}$ values, and evaluated the effect of the different procedures on PCR and sequencing analysis.

The specimens consisted fixed tissues of fruit-eating (frugivorous) bats of the Neotropical genus Artibeus (Chiroptera, Phyllostomidae) taken from preserved archival voucher specimens (Table 1) stored in the Chiroptera collection of the Zoology and Botany Department at the Institute of Biosciences Letters and Exact Sciences (Instituto de Biociências, Letras e Ciências Exatas, IBILCE) at São Paulo State University (Universidade Estadual Paulista, UNESP), São José do Rio Preto, SP-Brazil. We investigated muscle and liver tissues from museum specimens of five species of fruit-eating (frugivorous) bats of the genus Artibeus (Chiroptera, Phyllostomidae): A. fimbriatus, the fringed fruit-eating bat; $A$. lituratus, the great fruit-eating bat; A. jamaicensis, the Jamaican fruit-eating bat; $A$. obscurus, the dark fruit-eating bat; and A. planirostris, the flat-faced fruit-eating bat. For the experimental group we processed $5 \mathrm{~mm}^{3}$ pieces of liver and muscle tissue excised from archival voucher specimens of all the five bat species cited above which had been fixed in a mixture of alcohol and formalin (formalin-fixed) at least 20 years $(\mathrm{n}=123$ tissue samples). For the control group we processed $5 \mathrm{~mm}^{3}$ pieces of the same tissues which had been removed from freshly-killed A. lituratus and A. planirostris bats (2 specimens of each species) and fresh-frozen ( $\mathrm{n}=4$ tissue samples). Details of the bats and tissues are given in Table 1. The A. lituratus and A. planirostris bats which provided the fresh-frozen samples are in the 'least concern category' of the international union for the conservation of nature 'Red Book' and were not endangered species. The bats were humanly dispatched.

Immediately after removal from the voucher specimen each formalin-fixed tissue sample was washed with Hank's balanced salt solution (HBSS, containing (mM): $\mathrm{NaCl}, 1.4 ; \mathrm{KCl}, 70 ; \mathrm{Na}_{2} \mathrm{HPO}_{4}, 4.2 ; \mathrm{KH}_{2} \mathrm{PO}_{4}, 3$; glucose, 5; and phenol red, 0.045) for $15 \mathrm{~min}$, cut into small pieces and placed in a $15 \mathrm{~mL}$ sterile polypropylene tube containing $1 \mathrm{~mL}$ of HBSS and left to stand for $24 \mathrm{~h}$ at room temperature $\left(27^{\circ} \mathrm{C}\right.$ to $\left.35^{\circ} \mathrm{C}\right)$. After pretreatment, tissue fragments were removed from the tubes and transferred to a tube containing $5 \mathrm{~mL}$ pH 8 Tris-EDTA (TE) buffer (containing (mM): tris(hydroxymethyl)aminomethane (TRIS; Invitrogen, USA), 10; ethylenediaminetetraacetic acid (EDTA; Invitrogen, USA), and placed in $37{ }^{\circ} \mathrm{C}$ water-bath for one, four or seven days, the buffer being replaced every $48 \mathrm{~h}$ in the four and seven day treatments in order to remove alcohol and formalin residue and stabilize the $\mathrm{pH}$. Fragments were also placed in tubes containing $\mathrm{pH} 10.6$ glycine$\mathrm{NaOH}$ (GN) buffer (containing $0.2 \mathrm{M}$ each of glycine and $\mathrm{NaOH}$ ) and maintained in a water-bath at $80^{\circ} \mathrm{C}$ for $20 \mathrm{~min}$ or $37^{\circ} \mathrm{C}$ for one hour. This procedure was repeated, in duplicate. The fresh-frozen (control) tissue samples were

Table 1 - Number of preserved voucher specimens (n) of Artibeus frugivorous bats and liver and muscle samples analyzed. The experimental group tissues were formalin-fixed while the tissues in the control group were fresh-frozen.

\begin{tabular}{|c|c|c|c|c|}
\hline $\begin{array}{l}\text { Artibeus species and number } \\
\text { of specimens analyzed (n)* }\end{array}$ & Specimen accession numbers (DZSJRP) & $\begin{array}{l}\text { Muscle } \\
\text { tissue }\end{array}$ & $\begin{array}{l}\text { Liver } \\
\text { tissue }\end{array}$ & $\begin{array}{l}\text { Total tissue } \\
\text { samples (n) }\end{array}$ \\
\hline \multicolumn{5}{|l|}{ Experimental } \\
\hline A. fimbriatus (17) & $\begin{array}{l}\text { 16051, 16053, 16055-16057, 16059, 16065, 16070,16127, 16128,16132, } \\
16150,16151,16162,16166,16167,16184\end{array}$ & 18 & 21 & 39 \\
\hline A. lituratus (9) & $13118,14254,14257,14313,14514,15198,15583,15584,15592$ & 6 & 6 & 12 \\
\hline A. jamaicensis (7) & $13151,13214,13218,13220,13221,14361,14824$ & 7 & 7 & 14 \\
\hline A. obscurus (15) & $\begin{array}{l}14575,14735,14779,14821,14847,15304,15349,15528,16176,16192, \\
16252,16255,16265,16277,16285\end{array}$ & 27 & 25 & 52 \\
\hline A. planirostris (6) & $15667-15669,15696,16373,16374$ & 4 & 2 & 6 \\
\hline Experimental total (54) & & 62 & 61 & 123 \\
\hline \multicolumn{5}{|l|}{ Control } \\
\hline A. lituratus (2) & 18146,18152 & 1 & 1 & 2 \\
\hline A. planirostris (2) & 18153,18154 & 1 & 1 & 2 \\
\hline Control total (4) & & 2 & 2 & 4 \\
\hline Grand total (58) & & 64 & 63 & 127 \\
\hline
\end{tabular}

*All preserved specimens held at the Chiroptera collection of the Zoology and Botany Department at the Institute of Biosciences Letters and Exact Sciences (Instituto de Biociências, Letras e Ciências Exatas, IBILCE) at São Paulo State University (Universidade Estadual Paulista, UNESP), São José do Rio Preto, SP, Brazil. 
washed with HBSS, cut into small pieces and placed in a $15 \mathrm{~mL}$ sterile polypropylene tube containing $1 \mathrm{~mL}$ of HBSS. No treatment was applied prior to DNA extraction.

To extract DNA the suspensions of the formalin-fixed and fresh samples were centrifuged (Eppendorf Scientific, Hamburg, Germany) for five minutes at $3000 \mathrm{~g}$ and room temperature $\left(27^{\circ} \mathrm{C}\right.$ to $\left.35^{\circ} \mathrm{C}\right)$, the supernatant discarded and the precipitate transferred to an autoclaved microtube containing $300 \mu \mathrm{L}$ of lysis buffer (containing: Tris- $\mathrm{HCl}$, $10 \mathrm{mM}$; EDTA, $1 \mathrm{mM}$; NaCl, $100 \mathrm{mM}$; sodium dodecyl sulfate (SDS, Synth, Brazil) $2 \%(\mathrm{v} / \mathrm{v})$; and proteinase K, $4 \mathrm{mg} \mathrm{mL}^{-1}$ (Invitrogen, USA) and then incubated at $56^{\circ} \mathrm{C}$ overnight, with $1 \mu \mathrm{L}$ of $10 \mu \mathrm{g} \mathrm{mL} \mathrm{L}^{-1}$ RNAse solution (Invitrogen, USA) being added one hour prior to the conclusion of incubation. Extraction and purification of DNA was performed by adding $50 \%$ by volume of $5 \mathrm{M}$ potassium acetate solution, followed by of vigorous mixing and centrifugation at $3000 \mathrm{~g}$ and room temperature $\left(27^{\circ} \mathrm{C}\right.$ to $\left.35^{\circ} \mathrm{C}\right)$ for $10 \mathrm{~min}$. After centrifugation, the supernatant was removed and transferred to an autoclaved microtube containing 2.5 volumes of iced absolute ethanol to precipitate the DNA, which was pelleted by centrifugation at $12,000 \mathrm{~g}$ and room temperature $\left(27{ }^{\circ} \mathrm{C}\right.$ to $\left.35^{\circ} \mathrm{C}\right)$. The supernatant was discarded and the precipitate dried and then dissolved in $100 \mu \mathrm{L}$ to $200 \mu \mathrm{L}$ of TE buffer. The concentration of DNA was estimated by electrophoreses on $1.5 \%$ agarose gel containing $0.15 \mu \mathrm{g} \mathrm{mL}$ ethidium-bromide using $100 \mathrm{~V}, 1 \mathrm{XTAE}$ buffer, pH 8.0 (containing: Tris, $4.84 \mathrm{~g}$; EDTA, $0.5 \mathrm{M}$; and $1.14 \mathrm{~mL}$ glacial acetic acid) and a $100 \mathrm{bp}$ molecular marker ladder (Biolabs, England).

Each DNA extract was used as a template for PCR amplification using five primer pairs (Invitrogen, São Paulo) of different lengths, four amplifying mtDNA segments (12/16S 1-2, 1500 bp; 12/16S 3-4, 500 bp; CITB 4-5, $460 \mathrm{bp}$; and CITB 14-17, $460 \mathrm{bp}$ ) and a nuclear segment (RAG2, $1470 \mathrm{bp}$ ). Three different Taq DNA polymerases were tested, TaqGen polymerase (Biosystems), Platinum Taq DNA polymerase High Fidelity (Invitrogen) and Platinum Taq DNA polymerase (Invitrogen). The PCR reaction was carried out in a total volume of $15 \mu \mathrm{L}$ containing as template $100 \mathrm{ng}$ of sample DNA diluted in $200 \mu \mathrm{L}$ of TE buffer, 1.5 units of Taq DNA polymerase, $3 \mathrm{mM} \mathrm{MgCl}_{2}$, $7.5 \mathrm{ng}$ of bovine serum albumin (BSA) and $0.2 \mathrm{mM}$ each of dATP, dCTP, dGTP, and dTTP plus $1 \mathrm{X}$ enzyme mix (200 mM Tris- $\mathrm{HCl}, 500 \mathrm{mM} \mathrm{KCl}, 50 \mathrm{mM} \mathrm{MgCl}$ ). Amplification was carried out in a GeneAmp PCR System 2400 (Perkin Elmer), with the PCR protocol being varied according the specificity of each primer pair. In brief, the basic protocol consisted of an initial denaturation at 94 or $95^{\circ} \mathrm{C}$, followed by 35 variable cycles plus a final extension at $72{ }^{\circ} \mathrm{C}$. The modifications required by different primers are presented in Table 2. Amplifications were repeated for each of the three different Taq DNA polymerases.
Initially the performance of the different enzymes was tested using 30 successfully genomic DNA samples and a primer pair (CITB 4-5) that amplified a $460 \mathrm{bp}$ segment, these tests indicating that the Platinum Taq polymerase (not the High Fidelity version) was the most suitable product in our system. Fresh-frozen tissue samples from two A. lituratus and two A. planirostris specimens were used as control samples (fresh tissue DNA) and served as parameters to verify the amplification reaction conditions and quality of amplified fragments in all reactions. In the subsequent experiments we used the Platinum Taq polymerase and tested all the samples.

The reactions were first obtained with the primers that amplified the longest DNA fragments (12/16S 1-2 and RAG2). The sequencing reactions were conducted on the 27 best amplified samples, 19 from the formalin-fixed experimental group and eight from the fresh-frozen control group, selected by analyzing the concentration of amplified DNA after purification by DNA Sequencing Services of the Human Genome Study Center, University of Sao Paulo, Sao Paulo state, Brazil, which also developed the sequencing reactions. The amplified samples were initially purified with a GFX PCR DNA and Gel Band Purification Kit (Amersham), quantified with a Low DNA Mass Ladder (Invitrogen) and sequenced in a MegaBACE 1000 sequencer (GE Healthcare).The sequencing procedure was conducted according to the MegaBACE 1000 protocol with a DYEnamic ET Dye Terminator Kit (Thermo Sequenase II DNA polymerase - Code: US81090) and the same primer pairs as were used in the PCR.

The PCR amplification and sequencing reaction results were evaluated by electrophoreses on $1.5 \%$ agarose gel containing $0.15 \mu \mathrm{g} \mathrm{mL}$ ethidium-bromide using $100 \mathrm{~V}$, 1XTAE buffer, pH 8.0 (containing: Tris, $4.84 \mathrm{~g}$; EDTA, $0.5 \mathrm{M}$; and $1.14 \mathrm{~mL}$ glacial acetic acid) and a $100 \mathrm{bp}$ molec-

Table 2 - Reaction parameters for the five primer pairs.

\begin{tabular}{lccc}
\hline \multirow{2}{*}{ Step } & Number of cycles & Temperature $\left({ }^{\circ} \mathrm{C}\right)$ & Time \\
& CITB & CITB & CITB \\
& $12 / 16 \mathrm{~S}$ & $12 / 16 \mathrm{~S}$ & $12 / 16 \mathrm{~S}$ \\
& RAG2 & RAG2 & RAG2 \\
\hline Denaturation & 1 & 94 & $90 \mathrm{~s}$ \\
& 1 & 95 & $3 \mathrm{~min}$ \\
Denaturation & 1 & 94 & $2 \mathrm{~min}$ \\
& 35 & 94 & $30 \mathrm{~s}$ \\
Annealing & 40 & 95 & $50 \mathrm{~s}$ \\
& 35 & 94 & $60 \mathrm{~s}$ \\
Extension & 35 & 50 & $45 \mathrm{~s}$ \\
& 40 & 50 & $35 \mathrm{~s}$ \\
& 35 & 60 & $45 \mathrm{~s}$ \\
Extension & 35 & 72 & $70 \mathrm{~s}$ \\
& 40 & 72 & $2 \mathrm{~min}$ \\
& 35 & 72 & $90 \mathrm{~s}$ \\
& 1 & 72 & $10 \mathrm{~min}$ \\
& 1 & 72 & $40 \mathrm{~s}$ \\
\hline
\end{tabular}


ular marker ladder (Biolabs, England). The Sequence Analyser Program was utilized to produce the electropherograms. The sequences were designed in the BioEdit Sequence Alignment Editor (Hall, 1999) and the alignment was carried out with Clustal W v.1.81 (Thompson et al., 1994) and Blast 2 sequences. The quality of the sequence was evaluated using the electropherograms and alignments.

The suitability of formalin-fixed tissue collection extraction procedures for use in molecular studies was assessed based on three criteria, the concentration and length of recovered DNA fragments, the ability to amplify mtDNA and nuclear segments of various lengths and the quality of sequencing.

The number of samples used in each treatment and the number and percentage of samples from which DNA was successfully extracted (i.e., samples having a genomic DNA band with a high molecular weight) are shown in Table 3. Independent of tissue (muscle or liver) the best results for quality and concentration of extracted DNA were obtained from tissues which had been immersed in TE buffer for seven days, with genomic DNA being successfully extracted from tissues in $49(90 \%)$ of the 54 samples held in TE buffer for seven days (Table 3 ) as evidenced by satisfactory electrophoretic bands. The electrophoreses bands obtained using DNA from fresh-frozen liver tissue from A. lituratus (C), formalin-fixed muscle tissue from A. obscurus (lane 1) and formalin-fixed muscle and liver tissue from A. fimbriatus (lanes 7 and 8) are shown in Figure 1A. The results obtained with tissues which had been immersed in TE buffer for four days were also satisfactory, with $60 \%$ of the ten samples tested showing satisfactory bands. However, tissues which had been immersed in TE buffer for only one day showed satisfactory genomic DNA banding in only $18 \%$ of the samples 22 samples tested, with most samples showing a very low DNA concentration represented by degraded material appearing as smears in the agarose gel (Figure 1A, evincing DNA from formalin-fixed muscle tissue from A. obscurus - lanes 2 and 4, and A. fimbriatus - lane 6). The samples maintained in GN buffer for $20 \mathrm{~min}$ or $1 \mathrm{~h}$ produced highly degraded DNA, especially under the high temperature used for the 20 min experiments.

Several recent publications have reported the viability of the extraction of nucleic acids from formalin-fixed paraffin-embedded tissue (FFPE) (Coombs et al., 1999; Masuda et al., 1999; Shi et al., 2002, 2004). Among the methods proposed in these papers is that of heating tissues to high temperatures in alkaline solutions. Shi et al. (2002) argue that this treatment probably acts on tissues by of protein denaturation and hydrolysis, causing the rupture of cellular membranes and promoting disruption of the crosslinked bonds formed by formalin. However, contrastingly, we found that heating archival tissues at $80{ }^{\circ} \mathrm{C}$ for $20 \mathrm{~min}$ $\mathrm{pH} 10.6 \mathrm{GN}$ buffer, similar conditions to those used by Shi et al. (2002), was not very efficient. Apparently, the combination of high temperature and alkaline $\mathrm{pH}$ produced an increase in DNA degradation. Our results indicated that the most satisfactory methodology for minimizing the deleterious effects of formalin on DNA was that in which the fixed tissues were treated for at least four days at $37^{\circ} \mathrm{C}$ at a neutral $\mathrm{pH}$ of about $\mathrm{pH} 7.0$ to $\mathrm{pH}$ 8.0. This contrast between our study and the studies cited above may have been due to the fact that although the tissues used by us had been formalin-fixed they had not been paraffin-embedded, paraffin acting as an additional barrier to the action of temperature and alkaline $\mathrm{pH}$ on tissues and molecules.

The incubation time in the buffer was the most important element in improving the quality of extracted DNA. However, fixation and preservation conditions, and the preservation time of specimens in different collections can affect the DNA extraction process. We recommend the running of several pilot-tests in order to establish the most appropriate treatment for each kind of material or specimen used.

Table 3 - Combined number of formalin-fixed muscle and liver samples from preserved voucher specimens of Artibeus frugivorous bats tested in each treatment and the number (\% in parentheses) of successfully extracted samples. The samples were held in $5 \mathrm{~mL}$ pH 8.0 Tris-EDTA buffer (TE, containing: $0.01 \mathrm{M}$ Tris, $0.001 \mathrm{M}$ EDTA), changed every $48 \mathrm{~h}$, or $5 \mathrm{~mL}$ pH 10.6 glycine- $\mathrm{NaOH}$ (GN: $0.2 \mathrm{M}$ glycine, $0.2 \mathrm{M} \mathrm{NaOH})$. A dash (-) indicates that the specified time was not used for samples from that species.

\begin{tabular}{|c|c|c|c|c|c|c|}
\hline \multirow[b]{2}{*}{ Artibeus species } & \multicolumn{3}{|c|}{ Time in TE buffer at $37^{\circ} \mathrm{C}$ and number of samples } & \multicolumn{2}{|c|}{ Time in GN buffer and number of samples } & \multirow{2}{*}{$\begin{array}{c}\text { Total number } \\
\text { of samples }\end{array}$} \\
\hline & 1 day & 4 days & 7 days & 20 min at $80^{\circ} \mathrm{C}$ & $60 \mathrm{~min}$ at $37^{\circ} \mathrm{C}$ & \\
\hline A. fimbriatus & 10 & 5 & 12 & 8 & 4 & 39 \\
\hline A. lituratus & 2 & - & 8 & 1 & 1 & 12 \\
\hline A. jamaicensis & - & - & 10 & 2 & 2 & 14 \\
\hline A. obscurus & 10 & 5 & 20 & 15 & 2 & 52 \\
\hline A. planirostris & - & - & 4 & 1 & 1 & 6 \\
\hline Total & 22 & 10 & 54 & 27 & 10 & $123^{*}$ \\
\hline $\begin{array}{l}\text { Successfully extracted } \\
\text { samples }\end{array}$ & $4(18 \%)$ & $6(60 \%)$ & $49(90 \%)$ & $2(7 \%)$ & $0(0 \%)$ & $61(49 \%)$ \\
\hline
\end{tabular}

*Data refers to formalin-preserved samples only, hence the difference in the total number of samples analysed as compared to that shown in Table 1. 

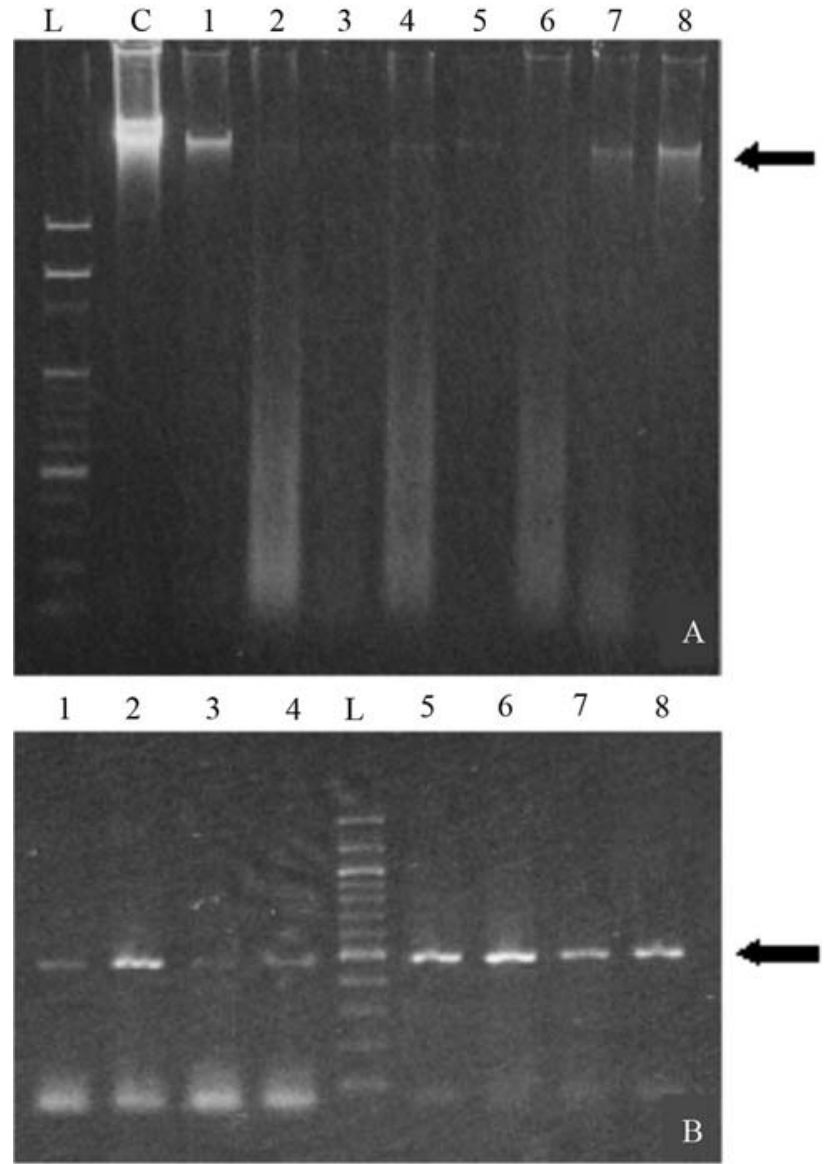

Figure 1 - Gel electrophoresis of A. DNAs (arrow) obtained from a sample of fresh-frozen control group liver tissue (C), lanes 2, 4 and 6 refer to formalin-fixed experimental group liver tissue kept in Tris-EDTA (TE) buffer for one day, while lanes 1,7 and 8 refer to formalin-fixed muscle (lanes 1 and 7) and liver (lane 8) tissue kept in Tris-EDTA (TE) buffer for seven days. B: Lanes 1 to 4 show 500 bp (arrow) PCR product produced with TaqGen polymerase using DNA template of formalin-fixed tissue, while lanes 5 to 8 show the same product produced using Platinum Taq polymerase. $\mathrm{L}=100 \mathrm{bp}$ molecular marker ladder.

The customary quantification of extracted DNA by spectrophotometry, was not undertaken in our study because sequence amplification by PCR is apparently most influenced by the quality of the DNA extracted from fixed tissues (Shi et al., 2002; Barea et al., 2004).

In the analyses of the performance of the different enzymes using the 30 samples and the primer pair CITB 4-5 (460 bp) the Platinum Taq polymerase High Fidelity (Invitrogen) generated non-specific fragments as well as the target $460 \mathrm{bp}$ segment but TaqGen polymerase (Biosystems) and Platinum Taq polymerase (Invitrogen) amplified only the target segment (Figure 1B), with Platinum Taq polymerase producing the best results in terms of the concentration and purity of the amplified fragments (Figure 1B columns 5 to 8 ). Therefore, the comparisons of the quality of the five primer pairs were based on the amplifications by Platinum Taq Polymerase.

The reactions were first carried out with those primers that amplified the longest DNA fragments (12/16S 1-2 and
RAG2). The efficiency of amplification was only about $30 \%$ (17 samples) and the most amplified segments contained only degraded material. The primers expected to amplify the shortest fragments (12/16S3-4 (500 bp), CITB 4-5 (460 bp) and CITB 17-14 (460 bp)) produced the best results because taken together they generated only one PCR product in $44(72 \%)$ out of the 61 DNA samples used for amplification. Although the expected band was always present, in most samples it was accompanied by smears, probably representing degraded DNA, RNA and residual proteins.

The four fresh-frozen samples (fresh tissue DNA) which served as controls for the amplification reaction conditions and quality of amplified fragments in all reactions, nearly always produced the expected amplified fragments with few smears, the exception being for fragments amplified with the Platinum Taq polymerase High Fidelity which usually produced more than one amplified fragment.

Our results indicate that the quality of the amplification reaction product is related not only to the efficiency of the polymerase enzyme and to the size of the amplified fragment but also to the quality of the extracted DNA and its level of impurity and degradation. However, a more efficient enzyme does not necessarily improve the quality of the amplified sample, as observed with Platinum Taq polymerase High Fidelity. Good results can still be obtained by altering some reaction parameters, such as the concentration of reaction components (Meunier and Grimont 1993; Davin-Regli et al., 1995; Halldén et al., 1996) and the number of amplification cycles (Shibata et al., 1994).

The concentration and degree of purity of amplified fragments are the most important prerequisites for successful sequencing reactions. Only 31 (45\%) of the 69 reactions amplified (representing 65 samples of DNA: 61 of formalin-fixed tissue and 4 of fresh-frozen tissue) reached the minimum concentration $(20 \mathrm{ng} / \mu \mathrm{L})$ required by Sequencing Services for a successful process. Two-way sequencing of the DNA band was conducted for 27 reactions (representing 19 from the formalin-fixed experimental group and eight from the fresh-frozen control group), with each amplified sample yielding two sequences for the reaction. The 27 samples generated 54 sequences, although 18 of these sequences were not of the expected size and showed a low identity of alignment. The remaining 36 sequences, consisting of 20 from muscle and liver formalin-fixed tissues and 16 from the fresh-frozen tissues, were reliable sequences according to the electropherogram and alignment analyses, although there were more gaps and unidentified bases in the sequences obtained from formalin-fixed tissues.

The fact that the DNA of 19 samples from the formalin-fixed experimental group (representing the five investigated species) that were submitted to sequencing were amplified in both the PCR reaction and during sequencing indicate that the amplification of samples obtained from 
formalin-fixed Neotropical Artibeus bat muscle and liver tissue is reproducible. Our study demonstrated that by establishing optimized parameters for purification and amplification of DNA sequencing reactions can generate reliable products for use in phylogenetic analysis, despite the fact that a number of number of sequence errors occurred with DNA extracted from the formalin-fixed tissue when compared with the sequences obtained from fresh-frozen tissue. These results suggest that DNA extracted from formalin-fixed tissue can be used in molecular studies of Neotropical Artibeus bats and that our methodology may be applicable to other groups of animals, although further studies are needed to confirm that our methodology is applicable to other groups. The information contained in biological collections could be useful for generating molecular data which may help clarify evolutionary and biogeographic aspects of problematic groups, particularly those that are difficult to collect, threatened by extinction or already extinct

\section{Acknowledgments}

The authors are grateful to Dr. Peter James Harris for suggestions regarding the English of the manuscript. We also thank the Brazilian agencies Coordenadoria de Aperfeiçoamento de Pessoal de Ensino Superior (CAPES) and Fundação para o Desenvolvimento da UNESP (Fundunesp) for financial support.

\section{References}

Barea JA, Pardini MIMC and Gushiken T (2004) Extração de DNA de materiais de arquivo e fontes escassas para a utilização em reação de polimerização em cadeia (PCR). Rev Bras Hematol Hemoter 26:274-281 (Abstract in English).

Coombs NJ, Gough AC and Primrose JN (1999) Optimisation of DNA and RNA extraction from archival formalin-fixed tissue. Nucleic Acids Res 27:12-17.

Corthals A and Desalle R (2005) An application of tissue and DNA banking for genomics and conservation: The Ambrose Monell Cryo-Collection (AMCC). Sys Biol 54:819-823.

Davin-Regli A, Abed Y, Charrel RN, Bollet C and de Mico P (1995) Variations in DNA concentrations significantly affect the reproducibility of RAPD fingerprint patterns. Res Microbiol 146:561-568.

Dubeau L, Chandler LA, Gralow JR, Nichols PW and Jones PA (1986) Southern Blotting analysis of DNA extracted from formalin-fixed pathology specimens. Cancer Res 46:29642969.

Faulkner SW and Leigh D (1998) Universal amplification of DNA isolated from small regions of paraffin-embedded, formalin-fixed tissue. BioTechniques 24:47-50.

Frank TS, Svoboda-Newman SM and His ED (1996) Comparison of methods for extracting DNA from formalin-fixed paraffin sections for nonisotopic PCR. Diag Mol Pathol 5:220-224.

Goelz SE, Hamilton SR and Vogelstein B (1985) Purification of DNA from formaldehyde-fixed and paraffin-embedded tissue. Biochem Biophys Res Commun 130:118-126.
Hall TA (1999) BioEdit: A user-friendly biological sequence alignment editor and analysis program for Windows 95/98/NT. Nucleic Acids Symp Ser 41:95-98.

Halldén C, Hansen M, Nilsson NO, Hjerdin A and Säll T (1996). Competition as a source of errors in RAPD analysis. Theor Appl Genet 93:1185-1192.

Hanner R, Corthals A and Dessauer H (2005) Salvage of genetically valuable tissues following a freezer failure. Mol Phylogenet Evol 34:452-455.

Masuda N, Ohnishi T, Kawamoto S, Monden M and Okubo K (1999) Analysis of chemical modification of RNA from formalin-fixed samples and optimization of molecular biology applications for such samples. Nucleic Acids Res 27:44364443.

Meunier JR and Grimont PAD (1993) Factors affecting reproducibility of random amplified polymorphic DNA fingerprinting. Res Microbiol 144:373-379.

Oliver I, Pik A, Britton D, Dangerfield JM, Colwell RK and Beattie AJ (2000) Virtual biodiversity assessment systems. Bioscience 50:441-450.

Shi SR, Key ME and Kalra KL (1991) Antigen retrieval in formalin-fixed, paraffin-embedded tissues: An enhancement method for immunohistochemical staining based on microwave oven heating of tissues sections. J Histochem Cytochem 39:741-748.

Shi SR, Cote RJ and Taylor CR (2001) Antigen retrieval techniques: Current perspectives. J Histochem Cytochem 49:931-937.

Shi SR, Cote RJ, Wu L, Liu C, Datar R, Shi Y, Liu D, Lim H and Taylor CR (2002) DNA extraction from archival formalin-fixed, paraffin-embedded tissue sections base on the antigen retrieval principle: Heating under the influence of $\mathrm{pH}$. J Histochem Cytochem 50:1005-1011.

Shi SR, Datar R, Liu C, Wu L, Zhang Z, Cote RJ and Taylor CR (2004) DNA extraction from archival formalin-fixed, paraffin-embedded tissues: Heat-induced retrieval in alkaline solution. Histochem Cell Biol 122:11-218.

Shibata D (1994) Extraction of DNA from paraffin-embedded tissue for analysis by polymerase chain reaction: New tricks from an old friend. Hum Pathol 25:561-563.

Thompson JD, Higgins DG and Gibson TJ (1994) Clustal W: Improving the sensivity of progressive multiple sequence aligment through sequence weighting, position-specific gap penalties and weight matrix choice. Nucleic Acids Res 22:4673-4680.

Yamashita K, Yoshida T, Shinoda H and Okayasu I (2001) Novel method for simultaneous analysis of p53 and K-ras mutations and p53 protein expression in single histologic sections. Arch Pathol Lab Med 125:347-352.

\section{Internet Resources}

Blast 2 Sequences (www.ncbi.nlm.nih.gov/blast/bl2seq/wblast2. cgi).

Centro de Estudos do Genoma Humano (http://genoma.ib.usp.br/ servicos/seq-produtos_pcr.php).

Tatusova TA and Madden TL (1999) Blast 2 sequences - a new tool for comparing protein and nucleotide sequences, FEMS. Microbiol Lett 174:247-250, http: www.ncbi.nlm. nih.gov/blast/bl2seq/wblast2.cgi. Associate Editor: Louis Bernard Klaczko 